\title{
Strategies, Performances and Profiling of a Sample of U.S. Universities in 2012
}

\author{
Angela Besana, Annamaria Esposito* \\ Department of Business, Economics and Law, IULM University, Milan, Italy \\ Email: angela.besana@iulm.it
}

Received 30 January 2015; accepted 6 March 2015; published 9 March 2015

Copyright (C) 2015 by authors and Scientific Research Publishing Inc.

This work is licensed under the Creative Commons Attribution International License (CC BY). http://creativecommons.org/licenses/by/4.0/

(c) () O) Open Access

\section{Abstract}

The global economic crisis is affecting performances of not-for-profits. At the same time donors are targeted by a pressing good-cause related marketing, so that the competition for philanthropy is particularly keen. U.S. universities can be public, not-for-profit and for-profit. U.S. not-for-profit universities are confronted with different marketing, fundraising and revenue diversification. Above all, marketing concerns customers and their segmentation and their purchasing-power exploitation; fundraising aims to gain the trustworthiness of donors, instead. The aim of this paper is the analysis of the revenue diversification of a sample of 100 U.S. not-for-profit universities according to IRS (Internal Revenue Service) Forms. These 100 U.S. universities had the highest 2012's revenues for the Guidestar ranking (www.guidestar.org). The cluster analysis gives evidence that the highest gain and the highest solvency are both connected with the implementation of revenue diversification for one profile. The most crowded cluster is the Marketing Expert with the second highest gain.

\section{Keywords}

Economics, Marketing, Performances, Cluster, U.S. University

\section{Introduction}

The revenue diversification is a main strategy at contemporary crisis times. Especially, this is a prevailing strategy for not-for-profits, who are struggling for survival when donors are very few and they are targeted by a pressing good-cause related marketing; so that the competition among not-for-profits for philanthropy is particularly keen.

U.S. universities can be public, for-profit and not-for-profit. Guidestar is the database of U.S. not-for-profits

*Annamaria Esposito wrote the third paragraph. 
with filing of their records (Statements of Revenues and Expenses, Financial Statements) according to standards of the Internal Revenue Service (IRS).

In this paper we investigate records of 100 U.S. universities whose 990 Forms can be downloaded at www.guidestar.org. These universities have the highest 2012's revenues according to the Guidestar ranking.

After having calculated revenues, expenses, net gains and net assets ratios, we cluster (k-means) this sample in order to focus on the Marketing Expert and the Revenue Diversifier according to prevailing "program service revenues" and the revenue diversification of the sample. We profile, as a consequence, clusters according to performances of marketing, fundraising, investing and other resource-raising.

The ultimate aim of the paper is a photo (classification thanks to cluster analysis) of average performances of a sample of U.S. universities, taking into account main strategies like marketing, fundraising and the revenue diversification in 2012. With the analysis of the current situation, we want to show how the focus on different strategies generates different performances, so that we can profile the sample according to prevailing strategies and performances. Gains refer to profiles of the Revenue Diversifier and the Marketing Expert. The Marketing Expert is 55 per cent of the sample.

This paper is a revised and expanded version of the paper entitled Economics and Marketing of USA Universities presented at International Conference on Applied Economics (ICOAE2014), Chania, 3-5 July 2014.

\section{Economics of U.S. Universities, Stakeholders and Revenue Diversification}

At hard times and with a financial crisis that is heavily damaging endowments, revenues and assets of not-forprofit organizations, these ones are struggling for resources and the revenue diversification is a leading strategy. Not-for-profits that rely solely on donors' dollars experience financial shortages when the economy worsens. The most diversified revenue is supposed to decrease the instability of one revenue source, creating greater organizational sustainability and efficiency. The most diversified revenue portfolio can be more profitable than focusing only on one main revenue source. This outcome is particularly relevant to not-for-profit organizations, which inherently experience high levels of revenue uncertainty, especially at crisis times when they face an increasing competition. As nonprofits face, at the same time, greater stakeholders' emphasis on efficient financial management and accountability, the question of whether diversification increases revenue stability, financial soundness, leadership and social capital becomes a must. As a matter of fact, not-for-profits are continually stimulated by a very competitive arena in order to reduce the revenue volatility and they realize that contributions, program service revenues, investment income and other revenues are all essential [1].

Stretching the range of revenues often includes the "extension" of the core business. For example, commercial activities are developed next to core businesses like arts, education, culture or any other business of the so-called not-for-profit cultural industry. Museums become locations for bookshops, restaurants, edutainment, conferences, meetings, events and any other opportunity in order to diversify and maximize revenues and in order to gain profits. Profits are not the mission of the not-for-profit organizations, but they are not neglected, as long as not-for-profits commit themselves to invest profits in the core business.

Together with the extension of the core business, the revenue diversification is a very important strategy in the U.S. not-for-profit universities, too.

In U.S. higher education, the role of private sources of funding has always been prominent. Particularly there are differences in the proportion of educational expenditure by source of funding for different level of education.

The available data [2] indicate that the United States spend more than 49 per cent of GDP per capita on each tertiary student and they strongly invest on tertiary education, devoting 2.8 per cent of their GDP to this type of education, more than the OECD average. The impact of the crisis was not negative as the public expenditure on educational institutions as a percentage of GDP remained constant in the United States. Private direct costs constitute more than $55 \%$ of the overall public and private direct investment costs for tertiary education

It should be always recalled that tertiary education is a complex definition and universities are one example of tertiary education. The tertiary education can include "long-stream" programmes that are theory based and aimed at preparing students for further research or to give access to highly skilled professions, such as medicine or architecture. Entry preceded by 13 years of education, students typically required to have completed upper secondary or post-secondary non-tertiary education. Duration is equivalent to at least 3 years of full-time study. The tertiary education can also include "short-stream" programmes that are more practically oriented or focus on the skills needed for students to directly enter specific occupations. The second stage of tertiary education refers 
to programmes that are devoted to advanced study and original research.

In the United States private funding comes mainly from households (more than 50 per cent of total expenditure), but more than $15 \%$ of expenditure on tertiary institutions is covered by private entities other than households. Public funds still represent 30 per cent of the spending distribution for the whole tertiary education.

The private sector can be divided into paying customers (tuition and fees, fees for services of auxiliary enterprises like university hospitals, etc.) and grant-makers (sponsors, foundations and other voluntary support). The education can, as a consequence, profit by expenditures and subsidies of multiple stakeholders.

U.S. tertiary institutions (universities as well as institutions that teach specific capacities of higher learning such as colleges, technical training institutes, community colleges, nursing schools, research laboratories, centers of excellence, and distance learning centers) obtain the largest proportions of funds from private sources. The proportion of expenditure on tertiary institutions covered by individuals, businesses and other private sources, including subsidised private payments, is more than 65 per cent, about twice as much as the OECD average.

If the focus is on the U.S. university, the revenue diversification is connected with the range of stakeholders that is always varying from students to clients and partners, from public administrations to community foundations, from investors to trusts, etc. From fundraising to marketing, positive performances of investments of assets and inventories included, the revenue diversification is implemented in order to gain resources from multiple stakeholders and consolidate leadership in a very competitive landscape [3].

While public funds are modest, prevailing resources remain tuition fees for U.S. universities. Program service revenues derive of the segmentation of paying students and paid services. The competition for students and their tuition fees is growing internationally. Many universities now compete in global markets for both students and staff who are likely to pay close attention to how different institutions perform.

Other revenues may derive from sales of financial instruments or other assets, profiling the University-Investor. Both the business stretching and the versioning involve institutional and faculty entrepreneurship (hospitals, football teams and other collateral business), philanthropy and other revenues from asset management.

Both public and private contributions can be, at the same time, as important as program service revenues, dividends and sales of assets. Fundraising is mainly developed through relationship marketing, mailing and community building, events and membership. Nevertheless, price and product marketing remains absolutely essential and it is a leading strategy next to fundraising.

The university governance is often confronted with a marketing vs. fundraising trade-off for resource allocation, where marketing that is typical of for-profit industries regards customers, their segmentation and their purchasing-power exploitation, and fundraising that is typical of not-for-profit industries corresponds to gain the propensity and trustworthiness of donors, both public and private fund-givers. The trade-off is faced when considering that the exploitation of the "willingness to pay" [4] is as important as the exploitation of the "willingness to donate".

Main stakeholders of USA universities are, first of all, students who are paying fees and any other clients who are paying a service, from consultancy to location rentals, from research to asset management [5]. With the ongoing crisis, marketing officers of USA universities have implemented credit schemes. The processing of paying has been eased with accurate financing schemes, from loans to risk-sharing and pooling so that the students' liquidity constraint has been surrounded.

Otherwise, it should be considered that U.S. universities have multiple clients. The range of their core business is quite wide. Few examples will be useful. For Stanford the Students Income is listed next to Nongovernment Research, Patient Care, Special Programs and Driving Range. For Princeton the accounting line of Program Service Revenues includes Tuition and fees, Graduate student housing, Dormitory fees, Food services, Conference and event services, Athletic fees, Advertising and Other.

Next to students and other clients, very important stakeholders of U.S. universities are philanthropists. They are not "simply" donors.

First of all, they are often research partners who are interested in focused alliances and joint venturing. The university places itself among the most significant producers of advanced research in the United States, a presence reflected in publications, research grants, inventions, laboratories, national and international prizes, and the engagement of the faculty, staff, graduate and post graduates whose work claims national and international attention. Research partners often mix the patron role with being client of the university research.

Secondly, they can be pure patrons who provide wealthy bequests for the university, above all, of their com- 
munity, so that they support a strong community identity.

The third category of philanthropists includes ex alumni too, who create clubs who are volunteering as for time, in-kind resources and money.

Other audiences can be thirdly listed as relevant stakeholders of U.S. universities. From the sale of assets and other tangibles or financial, U.S. universities diversify their revenues also including investing their assets. Above all, these revenues can include Interest on savings and temporary cash investments: the amount of interest income from savings and temporary cash; Dividends and interests from securities: the income from equities and securities; Sales of assets and inventories; Other investment income. Other revenues may include Rental incomes. Nevertheless, the fragility of contemporary financial markets has led to the cautious exploitation of these strategies. These resources are actually modest percentages of the revenue range.

\section{Not-For-Profit Universities' Strategies during Challenge Times}

Not-for-profit organizations have been facing complex market problems. Their survival depends upon grants from donors in a turbulent environment, in which not-for-profit organizations are competing, with the other players in the economic system, for funding and fulfilling their mission [6].

Considering the not-for-profit cultural sector at crisis time, difficulties have often resulted in a decrease in government support, because of increased need for public funding as residents lose jobs, income, and health insurance [7]. Regarding private universities, many also encountered adversities due to decreasing donations and due to the decrease in value of grants [8]. Furthermore, the crisis squeezes also students and their families. Generally in US enrolments are declining. Universities are offering student discounts to maintain tuition revenue, but in this case, discounts must be supported by the endowment.

Organisations confronting a demanding downturn and competition must be involved in marketing theories, concepts, strategies and techniques. This is why marketing is being applied by not-for-profit universities in US in order to gain consensus, competitive edge, and try to catch larger share market [9].

Not-for-profit universities need strong management with a solid strategic plan, which considers also marketing and communication. The last topic is very important during hard times, as not-for-profit universities need to spend more time managing relationships with their partners. They should improve their transparency about the impact of the downturn on the balance sheet. Nevertheless they should become more efficient and effective, and implement strong corporate brand communication, to engage major donors and trusts and build their brand and reputational goodwill.

Challenge times enjoin not-for-profit universities to make decision similar to for profit corporations to reinforce their position in the higher educational space. Colleges and universities respond to change while employing a more market-centric approach considering also partnerships and mergers to face crisis. According to Christensen and Horn (2013), it is estimated that $25 \%$ of colleges and universities will disappear or merger in the next 10 to 15 years [10]. This prediction may seem alarmist, but it reflects the difficulties encountered by US higher education sector. Mergers are seen as good strategies to strengthen offered services, but the decision may need to be discussed with donors and other stakeholders outside the institution in order to obtain their support.

According to the Gran Thornton Third Annual Report on the State of Higher Education in 2014, in order to compensate the reduction in the size of revenue from tuitions, of budgets or endowment, many universities have decided to enter the online education world by extending courses or enter degrees into the online market. In doing so, they sometimes share the burden of online programming by collaborating with other institutions or organizations [11].

That allows not-for-profit universities to grasp new market opportunities such as lifelong learning programs and online education, "massive open online courses," or MOOCs and market areas long-dominated by for-profit institutions. Especially online courses proliferate, because on one hand they increase accessibility, and on the other hand they reduce costs. Sometimes, courses are offered combining online and in-person learning.

According to the 2012's Higher Education Marketing Trends Benchmarking Survey by Cunet and Leads Council, traditional marketing methods are considered inadequate for reaching potential students [12].

This is why not-for-profit universities and colleges are also boosting web-marketing, content marketing, digital tools, email and mobile marketing, and social media to target, engage students, and diversify channels to achieve them with personalized campaigns.

Beyond the above mentioned strategies, not-for-profit universities should maintain credibility with parents, 
donors, alumni, employers and other stakeholders. They should enhance brand and assure that it is based on quality. They should find the unique attributes that make the institution distinctive with a unique selling proposition. They should share a culture shift toward involving everyone in marketing efforts.

According to William \& Omar (2014), corporate brand communication seems to be at an inflection point in its development, from a narrow approach, considering corporate brand as a tool for fundraising, to a wider one which considers the strategic role of corporate brand in driving long-term goals, in strengthening and aligning internal identity with external image, reinforce cohesion, capacity, and reputation [13]. Corporate brand is a multi-stakeholder concept and a multi-disciplinary concept effective in spreading who the not-for-profit organizations is. This is why it is becoming increasing important.

\section{Cluster Analysis of 100 U.S. Universities According to 2012's Performances}

In order to investigate U.S. universities, we referred to the database www.guidestar.org where 990 Forms (IRS Internal Revenue Service) are collected. These ones are the best accounting tool for our empirical purpose as they classify revenues in ten accounting lines so that performances of different strategies can be easily verified and the revenue diversification can be appreciated. In Table 1, a) c) and h) refer to the fundraising effort; b) refers to marketing; the other lines refer to the investment income and other earned income.

Above all, we collected 990 Forms of 100 universities with the highest revenues in 2012 and we examined not only their revenues but also their expenses, gain or loss, net assets and total assets.

As a matter of fact, the tax-exempt organization, which is listed in www.guidestar.org, is obliged to give the exact cost of fundraising, this one separated from other expenses. Marketing is included in the "Program Service Expense". "Management and general" includes miscellaneous costs that are not fundraising or marketing. This separation can be further evidence of different strategies whose expenses can generate diversified revenues. These ones can be directly connected to expenses of fundraising and marketing.

All revenue categories and expenditure ones were indexed to total revenues and total expenditures.

After having summed up revenues in four main revenue categories (Contributions, Program Service Revenue, Investment Income and Other Revenue), these ones were divided by Total Revenues. The Program Service Expense, Management one and Fundraising one were divided by Total Expenditures. In order to estimate the solvency of the sample, we also calculated Net Assets/Total Assets. In order to verify how much the sample is profitable, we calculated Net Gain or Loss/Total Revenues, too.

Using indexed data (ratios), we clustered (k-means) performances with the aim to understand what the effect of revenue diversification is. Moreover we profiled different types of universities according to prevailing revenues, expenses, profitability and solvency (Table 2).

All universities profit by a gain that is the highest, seven per cent of Total Revenues, when revenue diversification is implemented. Neither Contributions nor Program Service Revenues are, in this case, prevailing. In case of revenue diversification, the solvency is the highest of the sample, 77 per cent, too.

The range of expenses is quite the same for all universities: Program Service Expense between 85 per cent and 88 per cent; Management and general one between 11 and 13 per cent; the Fundraising one is never more than 2 per cent.

The analysis of variance (Table 3) confirms that revenue ratios are significant in order to split the sample in clusters. Next to revenue ratios the solvency ratio (Net Assets/Total Assets) is significant.

Expenses like Program Service and Management and General are not significant, as the whole sample is highly committed to core businesses and, as a consequence, Program Service Expense is never less than 85 per cent of all expenses (Table 3).

The prevailing profile is the Marketing Expert, both for cluster 1 and 3. The Marketing Expert has stakeholders like students, private grant-makers, sponsors, enterprises, research partners.

Nevertheless, though with only 14 universities, the cluster 2 is the Revenue Diversifier and the Revenue Diversifier profits by the highest gain of the sample, 7 per cent of Total Revenues (The Revenue Diversifier with the highest Gain). 31 per cent of revenues are Contributions. These ones are the highest ones of the sample: fundraising is an important strategy for the Revenue Diversifier as this is trying to maximize the willingness-todonate and, at the same time, the willingness-to-pay. As a matter of fact, 38 per cent of revenues are Program Service Revenues. Taking into account the performance of investments, 21 per cent of revenues are Investment Income. The Other Revenue is only 3 per cent, the highest percentage of the sample. The Revenue Diversifier is 
Table 1. Revenue lines of the 990 form.
a) Contributions, Gifts, Grants and Similar
b) Program Service Revenues
c) Membership
d) Interests and Dividends
e) Dividends and Interests from Securities
f) Rents or Other Investment Income
g) Sales of Assets
h) Special Fundraising Events Revenues
i) Sales of Inventory
j) Other Revenues

Our elaboration.

Table 2. 2012's Average performances and clusters of 100 U.S. universities (final cluster centers).

\begin{tabular}{lccc}
\multicolumn{1}{c}{ Cluster, Items in Every Cluster, Profile } & $\begin{array}{c}\text { 1, 31, The Marketing Expert with } \\
\text { the Lowest Gain and Net Assets }\end{array}$ & $\begin{array}{c}\text { 2, 14, The Revenue Diversifier } \\
\text { with the Highest Gain }\end{array}$ & $\begin{array}{c}\text { Expert with Gain } \\
\text { Expeting }\end{array}$ \\
\hline Contributions/Total Revenues & 0.10 & 0.31 & 0.13 \\
Program Service Revenues/Total Revenues & 0.86 & 0.38 & 0.81 \\
Investment Income/Total Revenues & 0.02 & 0.21 & 0.04 \\
Other Revenues/Total Revenues & 0.01 & 0.03 & 0.01 \\
Program Service Expense/Total Expenses & 0.88 & 0.85 & 0.87 \\
Management and General Expense/Total Expenses & 0.11 & 0.13 & 0.11 \\
Fundraising Expense/Total Expenses & 0.01 & 0.02 & 0.02 \\
Gain or Loss/Total Revenues & 0.03 & 0.07 & 0.06 \\
Net Assets/Total Assets & 0.47 & 0.77 & 0.70 \\
\hline
\end{tabular}

Elaboration with SPSS Software. In Cluster 1: DEPAUL UNIVERSITY-CHICAGO, EMORY UNIVERSITY-ATLANTA, FAIRFIELD UNIVERSITY-FAIRFIELD, FAIRLEIGH DICKINSON UNIVERSITY-TEANECK, GEORGE WASHINGTON UNIVERSITY-ASHBURN, GEORGETOWN UNIVERSITY-WASHINGTON, ILLINOIS INSTITUTE OF TECHNOLOGY-CHICAGO, LA SALLE UNIVERSITYPHILADELPHIA, MIAMI UNIVERSITY-CORAL GABLES, NEW YORK UNIVERSITY-NEW YORK, NOVA SOUTHEASTERN UNIVERSITYFORT LAUDERDALE, RENSSELAER POLYTECHNIC INSTITUTE-TROY, THE HOWARD UNIVERSITY-WASHINGTON, TRUSTEES OF BOSTON UNIVERSITY-BOSTON, UNIVERSITY OF DAYTON-DAYTON, UNIVERSITY OF HARTFORD-WEST HARTFORD, XAVIER UNIVERSITY-CINCINNATI et al. In Cluster 2: CARNEGIE MELLON UNIVERSITY-PITTSBURGH, DARTMOUTH COLLEGE-HANOVER, DUKE UNIVERSITY-DURHAM, MASSACHUSETTS INSTITUTE OF TECHNOLOGY-CAMBRIDGE, SOKA UNIVERSITY-ALISO VIEJO, STANFORD UNIVERSITY BOARD OF TRUSTEES-PALO ALTO, TRUSTEES OF PRINCETON UNIVERSITY- PRINCETON, UNIVERSITY OF NOTRE DAME DU LAC-NOTRE DAME, UNIVERSITY OF RICHMOND-RICHMOND, YALE UNIVERSITY-NEW HAVEN et al. In Cluster 3: AMERICAN UNIVERSITY-WASHINGTON, BAYLOR UNIVERSITY-WACO, BRANDEIS UNIVERSITY-WALTHAM, BUCKNELL UNIVERSITY-LEWISBURG, CALIFORNIA INSTITUTE OF TECHNOLOGY-PASADENA, COLORADO SEMINARY-DENVER, CORNELL UNIVERSITY-ITHACA, JOHNS HOPKINS UNIVERSITY-BALTIMORE, LEHIGH UNIVERSITY-BETHLEHEM, LOYOLA UNIVERSITY MARYLAND-BALTIMORE, LOYOLA UNIVERSITY-CHICAGO, MARQUETTE UNIVERSITY-MILWAUKEE, ROCHESTER UNIVERSITYROCHESTER, SAN FRANCISCO UNIVERSITY-SAN FRANCISCO, SEATTLE UNIVERSITY-SEATTLE, SOUTHERN METHODIST UNIVERSITY-DALLAS, SYRACUSE UNIVERSITY-SYRACUSE, TEMPLE UNIVERSITY-PHILADELPHIA, TRUSTEES OF THE UNIVERSITY OF PENNSYLVANIA-PHILADELPHIA, TULANE UNIVERSITY-NEW ORLEANS, UNIVERSITY OF DELAWARE-NEWARK, UNIVERSITY OF SOUTHERN CALIFORNIA-LOS ANGELES, UNIVERSITY OF ST THOMAS-ST PAUL, UNIVERSITY OF TULSA-TULSA, VANDERBILT UNIVERSITY-NASHVILLE, WASHINGTON UNIVERSITY-SAINT LOUIS et al.

Table 3. ANOVA analysis of variance.

\begin{tabular}{|c|c|c|c|c|c|c|}
\hline & \multicolumn{2}{|c|}{ Cluster } & \multicolumn{2}{|c|}{ Error } & \multirow[b]{2}{*}{ F Test } & \multirow{2}{*}{$\begin{array}{c}\text { Significance } \\
\text { Test }\end{array}$} \\
\hline & $\begin{array}{l}\text { Mean } \\
\text { Square }\end{array}$ & $\begin{array}{l}\text { Degree of } \\
\text { Freedom }\end{array}$ & $\begin{array}{l}\text { Mean } \\
\text { Square }\end{array}$ & $\begin{array}{l}\text { Degree of } \\
\text { Freedom }\end{array}$ & & \\
\hline Contributions/Total Revenues & 0.240 & 2 & 0.010 & 97 & 24.824 & 0.000 \\
\hline Program Service Revenues/Total Revenues & 1.241 & 2 & 0.012 & 97 & 107.094 & 0.000 \\
\hline Investment Income/Total Revenues & 0.189 & 2 & 0.004 & 97 & 44.596 & 0.000 \\
\hline Other Revenues/Total Revenues & 0.003 & 2 & 0.000 & 97 & 7.176 & 0.001 \\
\hline Program Service Expense/Total Expenses & 0.004 & 2 & 0.003 & 97 & 1.566 & 0.214 \\
\hline Management and General Expense/Total Expenses & 0.004 & 2 & 0.003 & 97 & 1.372 & 0.258 \\
\hline Fundraising Expense/Total Expenses & 0.000 & 2 & 0.000 & 97 & 4.895 & 0.009 \\
\hline Gain or Loss/Total Revenues & 0.013 & 2 & 0.004 & 97 & 3.426 & 0.036 \\
\hline Net Assets/Total Assets & 0.673 & 2 & 0.008 & 97 & 87.695 & 0.000 \\
\hline
\end{tabular}

Elaboration with SPSS Software. 
not only the most gainful but also the most solvent of the sample, with 77 per cent of Net Assets. This profile is, at the same time, Fundraiser, Marketing Expert and Investor. This profile has stakeholders like students, private grant-makers, sponsors, investors, leaseholders, renters, tenants and whoever is interested in businesses and assets of universities. The range of stakeholders is wider than in the Marketing Expert and this can have an impact on the higher gain of this cluster in comparison with clusters 1 and 3.

The most crowded cluster is cluster 3. Prevailing revenues are Program Service Revenues for 81 per cent of total ones. At the same time most of resources, 87 per cent, are spent for Program Services, from education to other businesses. The Net Gain is the second highest (6 per cent of total revenues) of the sample together with Net Assets (70 per cent of the sample). This profile can be called The Marketing Expert.

With 31 universities, cluster 1 is the second most crowded with the highest Program Service Revenue and the highest Program Service Expense. It is similar to cluster 3 but it suffers of the worst Net Assets/Total Assets and the lowest gain of the sample. Contributions, Investment Income and Other Revenues, Net Gain and Net Assets are the lowest ones of the sample. This profile can definitely be called The Marketing Expert with the lowest Gain and Net Assets.

Fundraising expense is 2 per cent on average. This Expense is not significant as it refers to small amounts of resources that universities mostly dedicate to 'the sale of education and other businesses'. As a matter of fact these 100 USA universities are quite similar for the composition of their expenses but revenue performances are quite different. Two main profiles emerge: the Marketing Expert and the Revenue Diversifier who is the most profitable and the most solvent.

\section{Conclusions}

USA universities are surviving thanks to an efficient resource allocation in marketing, fundraising and other financing strategies. Considering marketing strategies and tactics, not-for-profit and for-profit universities employ diverse marketing strategies to engage stakeholders (e.g., potential students, donors, sponsor). Not-for-profit ones are particularly facing a keen competition for resources at crisis times when donors cautiously screen good-causes. The fundraising effort is not providing the most resources as contributions are not prevailing in our sample.

As a matter of fact, the research gives evidence that a financing is profitable when it implies the revenue diversification. Multiplying audiences and financing strategies generate the highest gain and the highest solvency, though the Revenue Diversifier is not the most crowded cluster. The challenge is to manage a more complex portfolio of aims and strategies, to differentiate themselves in an increasingly competitive environment, and to protect and maintain academic quality and their ability to deliver it in the long term.

The Marketing Expert still remains the most crowded and the second most profitable profile, and social media are fundamental support in order to gain students' potential and effective interests.

Education and fiscal policies at macroeconomic levels should support and nourish these strategies, scheming proper standards and benchmarks and always aiming at the freedom, protection and promotion of education and research performances.

One of the limitations of this research is in the selection of the sample according to the core-business of education. U.S. universities are sometimes a holding of the main organization, associations (e.g. ex-alumni), foundations and other collateral institutions (trusts) that all manage the financing strategies of the core organization. It should be that all these organizations are investigated in order to estimate performances of financing strategies from marketing to fundraising.

It should be also considered that the period, here for the analysis confined, refers to 2012's performances. It should be much more meaningful to widen the period from 2008 up to now in order to estimate what is profitable and what is not on a long-run basis during and after the crisis.

\section{References}

[1] Carrol, D.A. and Stater, K.J. (2009) Revenue Diversification in Nonprofit Organization: Does It Lead to Financial Stability? Journal of Public Administration Research and Theory, 19, 947-966. http://dx.doi.org/10.1093/jopart/mun025 http://jpart.oxfordjournals.org/content/19/4/947.abstract

[2] OECD (2014) Education at a Glance 2014: OECD Indicators. OECD Publishing, Paris. http://dx.doi.org/10.1787/eag-2014-en 
[3] Cantwell, B. and Barrett, J.T. (2013) Global Status, Intra-Institutional Stratification and Organizational Segmentation: A Time-Dynamic Tobit Analysis of ARWU Position among U.S. Universities. Minerva, 51, 195-223. http://dx.doi.org/10.1007/s11024-013-9228-8

[4] Choi, A.S. (2009) Willingness to Pay: How Stable Are Estimates? Journal of Cultural Economics, 33, 301-310. http://dx.doi.org/10.1007/s10824-009-9103-5

[5] Leslie, L.L., Slaughter, S., Barrett, J.T. and Zhang, L. (2012) How Do Revenue Variations Affect Expenditures within U.S. Research Universities? Research in Higher Education, 53, 614-639. http://dx.doi.org/10.1007/s11162-011-9248-x

[6] Dolnicar, S. and Lazarevski, K. (2009) Marketing in Non-Profit Organizations: An International Perspective. International Marketing Review, 26, 275-291. http://dx.doi.org/10.1108/02651330910960780

[7] Dolnicar, S., Irvine, H. and Lazarevski, K. (2008) Mission or Money? Competitive Challenges Facing Public Sector Nonprofit Organizations in an Institutionalized Environment. International Journal of Nonprofit and Voluntary Sector Marketing, 13, 107-117. http://dx.doi.org/10.1002/nvsm.311

[8] Humpheys, J., Electris, C., Filosa, J. and Grace, K. (2010) Educational Endowments and the Financial Crisis: Social Costs and Systemic Risks in the Shadow Banking System. Center for Social Philanthropy, Tellus Institute, Boston.

[9] Kotler, P. and Levy, S. (1969). Broadening the Concept of Marketing. Journal of Marketing, 33, 10-15. http://dx.doi.org/10.2307/1248740

[10] Christensen, C.M. and Horn, M.B. (2013) Innovation Imperative: Change Everything. New York Times, 13 November 2013.

[11] Grant Thorton LPP (2014) The State of Higher Education in 2014. http://www.grantthornton.com/HigherEd2014

[12] Cunet and Leads Council (2012) Higher Education Marketing Trends Benchmarking Report. http://www.cunet.com/wp-content/uploads/2012/06/CUnet_2012_Benchmark_ForProfit.pdf

[13] Williams Jr., R. L. and Omar, M. (2014) How Branding Process Activities Impact Brand Equity within Higher Education Institutions. Journal of Marketing for Higher Education, 24, 1-10. http://dx.doi.org/10.1080/08841241.2014.920567 